\section{international journal of \\ stomatology \& \\ occlusion medicine}

\title{
Retraction note: Aeronautic dentistry: an upcoming branch
}

\author{
Kanwaldeep Singh Soodan · Pratiksha Priyadarshni · Jatinder Pal Singh
}

Published online: 5 May 2015

(C) Springer-Verlag Wien 2015

Retraction note to: J. Stomat. Occ. Med. (2014) 7:91-96. DOI 10.1007/s12548-014-0113-3
This article has been withdrawn by Professional Media Department, Springer-Verlag Wien due to proven plagiarism.

The online version of the original article can be found under doi: 10.1007/s12548-014-0113-3.

Dr. K. S. Soodan $(\bowtie) \cdot$ Dr. P. Priyadarshni · Dr. J. P. Singh Department of Oral and Maxillofacial Surgery, M.M. College of Dental Science and Research,

Mullana, Ambala, 133203 Chandigarh, Haryana, India

e-mail:dr.kanwal@rediffmail.com 